

Royal United Services Institution. Journal

\title{
Is a National Army Necessary for the British Isles, and if so, How Should One be Formed and Trained?
}

\section{Captain J. B. G. Tullough p.s.c.}

To cite this article: Captain J. B. G. Tullough p.s.c. (1907) Is a National Army Necessary for the British Isles, and if so, How Should One be Formed and Trained?, Royal United Services Institution. Journal, 51:348, 184-198, DOI: 10.1080/03071840709431345

To link to this article: http://dx.doi.org/10.1080/03071840709431345

曲 Published online: 11 Sep 2009.

Submit your article to this journal $\pi$

Џll Article views: 7

Q View related articles ¿ 




\title{
IS A NATIONAL ARMY NECESSARY FOR THE BRITISH ISLES, AND IF SO, HOW SHOULD ONE I3E FORMED AND TRAINED?
}

\author{
By Captain J. B. G. TULLOCII, p.s.c., Ind R.O. Fork'shire Light \\ Infantry.
}

A NATIONAL Army may be defined as a trained force that can be expanded from a weak peace establishment to a force that would contain, if required, the whole available physically fit manhood of the nation for war. With the exception of Eugland all great nations have such National Armies, and we do not possess one because the nccessity for such has never been understood by the British nation, which pins its faith entirely to the Navy. There are two very distinct opinions on the question whether a National Army is necessary or not.

The first is known as the "Blue Water" School, which believes that the British Navy is so all-powerful that not even a hostile dinghy could land its crew on the British coast.

The second is the "Invasion Bogey" School, which has ever. before its eyes the vision of hordes of Germans marching unopposed on London.

But there is a large and steadily increasing number of those who are of opinion that the ideas of the Blue Water School are anything but justified, and that if the nation contiuues to trust in them wo shall, in plain English, be living in a fool's paradise. There is now a special reason for the increasing feeling of uneasiness with reference to maritime defence, and that is the steady and very systematic increase of the German Fleet, and the avowed determination of the German people to become our equals, and in time our masters, on the ocean. Race dislike, the Germans say distinctly, they have none, but they state plainly that they want our possessions and trade, and mean to have them. This state of the uational feeling is by no means a recent nowspaper production; it has been growing and increasing steadily ever since the Franco-Prussian WVar. "Deutschland über alles " has taken the place of "Die Wacht am Rhein."

The exponents of the Blue Water School of former days went for the enemy whenever they could find him, chasing their foes round the world. But could a similar course of action be ventured on now ? That France will always be on our side, because the nations are so friendly just now, is to utterly ignore even the most modern history of the two countries. With a hostile Navy at all approaching ours in strength, and having its bases only a day or two's steaming from us, what Government, strong or weak, would be allowed by the people to send away from home waters the only force which, without a National Army, would stand between them and destruction? 
But even if our Navy succeded in shutting up lostile fleets in their ports, how do the "Blue Water" exponents propose to iring the war to an end? We must have an Army to complete what the Navy has begun. The Japanese even used an Army to destroy a flect.

In 1782-83, the French Admiral, Sufiren, fought five battles with Admiral Sir E. Hughes in Indian waters, and although he could not drive the English fleet from off the high seas, Suffren succeeded in landing French troops in India in sucl numbers as to imperil the supremacy of English rule in Southem India. MIoreover, although II ughes' flect was still very much "in being," Sufren captured Trincomalec, landing troops for the purpose.

$\Lambda$ s regards the effect of even small raids, "General Ilumbert, with over 1,000 French troops, in Killala Bay, in 1798, practically neutralised the Irish garrisons of 100,000 men for 17 days, and compelled Jord Cornwallis to cry out for further reinforcements."

"In 1796, though the British fleet was blockading Brest, yet a French-expedition slipped out from the Goulet, and the adjoining bays, and got away to Ireland with 20,000 nen without serious opposition. And 36 out of 43 French ships were off Cape Clear, and those that reached Bantry Bay remained there for over a fortuight without being interfered with by the British Navy."

Mines and submarines have compelled modern fleets to keep a very long way out to sea when on blockade duty, thus facilitating the cscape of the enemy, who, owing to steam power, can now put to sea on the darkest and stormiest nights. To cnable the Navy to act as they did so gloriously a hundred years ago; a National Army, to protect the country and permit of tho fleet going wherever necessary to attack the enemy, is a necessity.'

Ther: is another reason also why a National Army has become necessary. Up to within recent times, when great strategical railways were unknown, we had no land frontiers which could be scriously threatened by great Powers. But, as the late war in Manchuria has shown, we are now in a very different position.

- In the Bocr IVar, when our enemies numbered at the outside some 50,000 or 60,000 , we had to put a quarter of a million men into the field, leaving the United Kingdom defenceless as far as an Army was considered.

With regard to -India, the strength of the force which may some day be required to save that country, has already been clearly stated and agreed to by the highest authorities, political as well as military, and would be so far in cxcess of the vumbers sent to South Africa that nothing but a National Army behind the Regular forces would supply the numbers required. Loid Roberts' estimate is 500,000 troops for the first year of the war for the field armies, and line of communication troops, and for keeping India quict; and to make up wastage, and increase. the power of the field armies as the railways developed, nearly 300,000 men during each succeeding year of the war. Towards this number Sir E. Elles says that India can supply, exclusive of Imperial Service troops, a total field army of 139,000 men.

There are also our Treaty obligations to be observed with' regard to the violation of Belgian territory in case of war between Germany and France. 
Moreover, the question of the defence of Canada must be considered. This country has a frontier of 3,500 miles towards the United States, and a population of $6,000,000$ against $70,000,000$.

War between ourselves and the United States would certainly. require us to land an Army to help Canada far beyond the capabilities of our present Regular Army.

$$
\text { * } \quad \text { * } \quad *
$$

The material which we have at present, out of which to form our National Army, consists of the Militia, Yolunteers, and Yeomanry. The Regular Army is not considered, as it will have been already probably sent abroad. The Reserve of the IRegular Army will have -been very soon cxhausted in the process of bringing our "squeezed lemon" battalions up to strength.

The Militia canuot be looked upon, as at present constituted, as an efficient fighting force. "The majority of the meu composing the Militia are practically the riff-raff and failures of socicty. Thoy are mostly half starved during the winter, and induced to come out -for a month's training during the summer for the sake of the few shillings and the food they obtain." Their average of pliysique and intelligence is very low. Their non-commissioned officers are of an inferior class. The permanent staff consists, as a rule, of Regular sergeants who have married and want an easy life, or of those who have been recommended for service with the Militia by their company officers, because it was desired to get rid of them.

"Militia officers are of two classes: one, that of the youths who, being somewhat deficient in brain power, go into the Militia because they think that it is an easy method of getting into the Regular Army; the otlier, composed of those who look upon a month's training as a pleasant change from the humdrum of their everyday life. Neither class over-works itself professionally."

With regard to the training of the Militia, the least said tho better. . The unit comes out for a month, goes probably to an already overcrowded training ground, and everything is.hurried through and slurred over. If there is ever a field day, or a day's training off the range, the proceedings are farcical and unreal to a degree.

The Voluntecrs are also at present uscless as a fighting force. I would guarantee that any German company of 250 men would go through any ordinary Volunteer battalion like a Kuife through butter. Certainly there are a few corps, like the London Rifle Brigade, the London Scottish, etc., who should make a good fight, but these exceptional corps are so few that they do not leaven the mass. And if Volunteers are not to fight Continental troops, why spend money on them at all? If they are to fight, say German troops, then must they not on the day of battle be equally well trained, man for man, and officer for officer, as their opponents? Politicians tell their audiences that we shall have plenty of time after war is declared in which to train them to the right pitch. That I doubt. But even so, where at present are tho trained officers who will teach them, and where is the land on which to train? Are these considerations that can bo left till war is declared?

There are some 25,000 Ycomanry. If they were only as efficient with the small amount of drill they do, as they are beautiful to look at in their uniforms, we should have no fear of scouting duties 
being badly done. But, unfortunately, this is not tho case. If Yeomanry are ever to be sent abroad they would require at least a year's hard training to make them fit to cope with Continental cavalry. If they are only to be used in England as scouts, in case of invasion, there are too many of them. England is not a cavalry country, and lialf the present number of Yeomen well trained, the remainder being mounted on bicycles, would be a cheaper and more effective force. Evidently our new National Arny must be very differently organised and trained to the foregoing.

In the present state of fecling in England towards the Army, it is impossible to use any form of compulsion in order to obtain recruits for it, neither can any great outlay of noney be expected. "Efficiency with economy" is a very taking political platform plurase, but there is another expression, "Nothing for nothing," which, in commercial England, will very soon put an effectual stop to any endeavour to produce a National Army by making those who form it put their hands deeply into their own pockets, whilst others stand by and jeer.

We want our National Army to be a well trained and efficient one. Now, no Army can possibly be efficient without ranges to firc on, and ground on which to manœuvre. These require money, and any scheme leaving them out of consideration is useless. No scheme for forming our new Army will ever near completion unless we have a strong Government in office, likely to remain there for some years, and a Minister for War who, in spite of all the opposition in Parliament from those who thinik that their interests are threatenod, determines to carry the new scheme through to the end. It seems to be an extraordinary thing that although there are at present about 358,000 Auxiliary troops in England, there is no representative for these troops on the Army Council. If we desire to form a National Army that the people are to take an interest in, and "run" themselves, as one might say, it is very evident that we must not attempt to form rules and regulations for this $A$ rmy in the same cast-iron way that prevails in the Regular Army. "The people will not stand it. There must be a give and take, and the trades, pursuits, ideas, leisure, and desires of the population must be considered. To convey these ideas, and keep a, hand on the pulse of the popular opinion, must then be the function of the representatives of the National Army, who should be members of the Army Coungil, for advice purpososes.

Therefore, it is proposed that a member representing the National Army should be added to the Army Council, and that whenever thero is a meeting of tho Army Council to deternine any far reaching changes, that this member be present, and that attention be paid to his ideas. Similarly in each of the present commands there should be an expert officer of the National Army to give advice when asked for to tho General Staff of the command, and to communicate tho ideas of the district to the member of the National Army at the Var Office.

The terms Auxiliary Forces, Militia, Volunteers, etc., should be abolished. There should be merely the Regular Army, and belind that "The National Army."

- This Army will, however, be composed of two classes: the one being units formed from men willing to serve abroad, the other units composed of men who only wish to serve for Home Defence.

VOL. LI. 
Every unit to have its own Reservo.

We have seen that it may be necessary to send troops of the National Army. abroad to heip the Regular Army. I consider it to be better to send units complete with offerers and men, than driblets of companies to be atiached to other corps, aud for this reason:- It. may, for strategical reasons, be necessary to form other armies than the one, or ones already operating. If there are a number of corps ready with their own reserves, then the formation of the Auxiliary Armies is simple. The Regulars must keep up the supply to replace their own wastage by a proper system of forning and training depôt. battalions at the reginental depôts.

How are the men for the National Army to be obtained? I have made exlaustive inquiries in the country, and I find that no proper organised system exists at present for recruiting for the present Auxiliary forces. For the National Army this must be changed. The people in the country are in absolute iguorance concerning the Army. They seldom see a soldier, and they know nothing whatever about the Volunteers in many places. Civilians also complain that the Army keeps itself apart from them, and that they are not allowed to enter barracks, etc. Even at Strensall, where any number of Militia battalions traiu, I have found that inany eligible youths have not joined the Volunteers because they have not been asked to do so. On the other liand, a sergeant of Volunteers came round recruiting for his corps to Stamford 13ridge, a village a few miles from York. By personally interviewing the eligible youths he obtalned 7 or 8 recruits in three days.

Now this shows us that every village in the United Kingdom must be visited if we are to impress upon the able-bodied male population what is required for the National Army. No anount of political speeches by War Ministers will affect recruiting. The village populations and the mass of the town populations never read his speeches. WVe must get at the people by direct means. To do this, system is required. We alrcady have numberless cadres of Volunteers and Militia scattered all over the country, all with headquarfers in various towns.

Using theso present headquarters as centres, I propose to allot to each a number of parishes. To each parish is allotted a National Army Recruiting Agent. This agent is to make a liouse to house visit, and personally interview all eligible young men, and impress upon them the advantages that a military training would give them. This is not such a difficult undertaking as it would at first sight appear. If we take Yorkshire, a fairly large county, as an example, we can see how the scheme rould work by going into detail.

$A$ glance at the $A$ ppendix $A$ will show that each agent is responsible for only $216 \mathrm{men}$ on an average. Surely there is no great difficulty in this. Of course, parishes differ in the numbers contained in each. If a parish has a particularly large number of inhabitants, more than one agent is allotted; if the parishes are small, oue agent can do several. In any case, the number of agents shown in Appendix would not be exceeded.

These agents can be the postmen of the district, old pensioners, picked men of the local National Army battalion, village policemen, rural policemen, etc., and their duties are to see that rocruiting 
literature and pamphlets, ciescribing the National Army and its aim, etc., are delivered to every eligible male inhabitant of their allotted area. We must have recruiting literature, posters, etc., distributed. We must advertise, in fact. We must advertise our National Army so that every man in the British Isles knows about it. How is adver: tising for the legulars carried out? Very badly indeed. Posters are exhibited outside police courts, outside the prison-like walls of old fashioned barracks, situated in filthy slum areas in big manufacturing towns, where nobody but undesirables sce them, or else they waste their allurements on the desert air of places like Salisbury.Plain and Aldershot, where nobody ever sees them except the men who have becn already caught. "In business, when a firm is not doing great sales, a certain sum of money is taken from capital, and expended oil advertising, and generally with good results to the firm." We must do the same. If the War Oflice cannot invent a means of distributing. alluring posters and pamphlets in the most remote village and hamlet, then get the Daily Hail or f'imes to do it. But when advertising remember that the mass of the pcople read lleynolds' Neu'spuper. and the l'eople, and not the 'imes. But I think my National Army agents should be able to do it. An allowance for repair and upkcep of their private bicycles, and a very small retaining fee per quarter would suffice to enlist the services of National Aray Recruiting $\Lambda$ gents. As uniform is a great attraction to village populations, smart ex-mon-commissioned officers, especially those who had medals, should be permitted, even after they had left the colours, to wear the uniform of the local National Army battalion whenever engaged in recruiting. The adjutants of the National Army battalions to supervise the agents.

To save expense and to avoid unnecessary changes, the present headquarters of the present. Auxiliary forces could be made use of for forming the National Army units. To every present headquarters should be allottect so many parishes. To each collection of parishes, allotted according to population, are assigned the provision of so many battalions.

For instance; in the N.W. of Yorkshire the number of parishes allotted to Richmond-might, perhaps, only be sufficient to produce one battalion of the National Army for home service, and one for forcign service, whilst the parisles allotted to Huddersficld might produce two or three lome service National Army battalions, and one foreign service National Army battalion.

This brings me to the terms and forms of service.

We have seen that it will be necessary to send a certain number of National Army battalions abroád. Now, when a man is asked to cnlist in the National $\Lambda \mathrm{rmy}$, he will be asked whether he desires to enlist for service abroad in case of emergency, or only for home defence.

The Foreign Service National Army battalion is to be composed of men, who, for say an ańnual bounty, are preparod, when called out, to serve abroad if required. These battalions must, of course, receive a higher training than the Home Service battalions, as they might be required at an early stage of the war.

Every unit, whether a Home or Foreign Service one, to have its orn Reserve. 
This, then, will produce three categories in the British Army:-

1. The Regular Army, with its Reserves, ready to mobilise at a day's notice, and be transported anywhere when transport is ready and occasion requires it.

2. The National Army Foreigu Service battalions, batterios, and squadrons, with their Reserves, ready to follow the Regulars if required.

3. The National Army Home Dofence Army, with its Reserves, ready to mobilise and commence further training the moment war appears to be unavoidable.

It must be assumed that we are going to give our different levies, or categories of the National Army, a much more piactical and complete training than they at present receive. This will at once cause a good number of those at present in the Auxiliary forces to resign. But on the other hand, we have spread our recruiting agents throughout the land, and where one man thought about the Army, now 20 would. Therefore, our numbers may diminish from one cause, but rise from anothes:

Moreover, there are really more Volunteers at present than we requirc. Some battalions are over 1,000 strong, and this is more than the ordinary Volunteer colonel can command. Therefore, fixing a limit to the number allowed to be actually serving at ono time with a National Army battalion, and granting that although many men go, others will take their place, 1 think we may safely assert that we might fix the strength of battalions at, say, 500, and cavalry regiments at 400 . A battalion of 500 willing men, organised in 8 companies of 60 men each, with 20 over for the band, is as many as can be found in most of the "squeezed lemon" Regular battalions at home. But each company must have at least 60 men ready and willing to drill when required. Otherwise the numbers would be too small for practical company work, and then we should have to increase the establishment.

The question as to the age at which men are to be taken is most important. In a purely voluntary Army' composed of men in cmployment, we must think of the convenience of employers and employed. Otherwise our recruiting for the National Army will fail. We must study here the wants of the people. I have discussed the subject with employers of labour, and it appears that the younger the men are taken the better. Employers say that a youth is of least use. when he has only left school a short time, and before he has become a skilled and expert workman at his tradc or profession. Moreover, they state that they would be only too willing to allow every convenience to lads in their employment who desired to drill, bocause they all see that military discipline is good for their otherwise very independent. employées. As a matter of fact, many. cmployers of labour are in favour of some form of compulsory service, in order to engrain even tho smallest labits of obedience in their workmen. But, on the other hand, it would bo useless to take lads who were too young, as they would be unable to bear the fatigue of training. Seventeen appears to be a suitable age. The lads are then sufficiently strong to be able to handle their rifles and march, and nobody at 17 is an expert or skilled artisan whose absence from work would be grudged by an employer. 
According to present Volunteer regulations a man culisted in a Home Service National Army battalion would, in 5 years' service, do a minimum of 40 drills of 1 hour duriug his recruits' course, and 10 drills of 1 hour for company training in the first year. Total 50 lours. During the next 4 years he need only do 40 liours. A grand total in 5 years of 90 liours.

Colonel Pollock has slown us that in 6 months, by hard work, one can turn out a fairly well trained man, but still, only an amateur. Now, climinating all setting up drill, gymnastics, etc., as not absolutcly necessary for a Home Defence man, we should requiro at least an average of 2 lours' drill daily throughout the 6 months, or 360 hours. This is exactly four times what the present Volunteer doing a minimum course does, before he can be considered as of any value as a soldier. But if we want to form a Reserve for each battalion or regiment, we must fix a limit of time during which each man serves with the colours of the National Army battalion. $\Lambda$ period of 5 years seems sufficient. At the end of that time the man will bo becoming an expert at his trade or profession, and will not be able to spend so much time drilling. But aluring this five years the National Army man must be prepared to put in a minimum of work four times greater than is the ininimum at present.

After all, this is not asking too much, as many Voluntcers do that now, and we must eliminate all thoso who join the present Voluntecrs merely for the salse of wearing a uniform and shooting for prizes at rifle meetings.

The Foreign Service National Army battalions must have still more training. For these, at least a six montlis' course for recruits will be necessary. After that six weeks annually.

Now, in order to make the training periods elastic and fit in with the work of the would-be recruit, any man who so desires should bo allowed to come up to battalion headquarters and do his drills at any convenient time of the year.

The battalion headquarters to be the piesent regimental depôts and Volunteer and Yeomanry headquarters, and if that does not suffice, then the drill halls and armouries of the present outlying Volunteer company centres could be used. At present, at our regimental depôts, nothing is done in the way of practical training beyond preliminary gymnastics and such simple exercises as forming fours, marching correctly, and handling arms. There should be a squad for work of a higher nature, such as skirmishing, taking cover, attack practice, sentry work, etc. This squad should be at work all the year round, and be under picked instructors, not the usual depôt. instructor, who is generally a most inferior non-commissioned officer.

Once a month names could be sent in by the adjutants of National Army battalions, of men desirous of being driller, to the officer who superintended the work of this advanced squad, and anybodyshould be allowed to join. It should not be requisite for men of this squad to live in barracks, or even to be fitted with a uniform. All that is requisite is, that any man having given in his name and appearing on his bicycle, from some miles away, say, should be given the training he requires. Numbers of men living near depôts, whether they belonged to Home Service or Foreign Service National $\Lambda \mathrm{rmy}$ 
battalions, would like to gain their military training this way. The test for efficiency is not to be whether a man attends so many drills, or makes so many points in musketry practice.

The present method of calling a man an " cficient" Voluntcer just because he happens to make-a certain score on the range and does so many drills is absurd. The public is defrauded by the present system. A Volunteer C.O. told me that one of his men was physically unfit to march, but could just do his annual drills, and had to be brought down to the range in $a$ cab. Once on the range ho could lio down and fire his requisite rounds, and being a good shot, made the correct score and became reckoned as an efficient, and counted in the numbers carming capitation grants. There are hundrods of similar cases, but as under the present system capitation grants are what provide the money for running the battalion, fraud in showing men as efficient when they are useless is bound to take place.

Capitation grants must be done away with.

It would not be difficult to estimate how much it would cost to run a battalion of 500 strong for a year, cverything included. That amount should be allowed to be spent by the battalion so long . us the numbers of men were forthcoming.

The real tests for efficiency to be:-

a. Medical inspection. Anybody not fit to serve abroad to be relegated from a Foreign Service battalion to a Home Service one.

b. For a Home Scrvice battalion a thorough knowledge of handling a rifle, skirmishing, attack and dofence practices, art of taking cover and knowledge of outpost duties.

For a Foreign Service battalion the above, but advanced and rear guards, digging shelter trenches, etc., thrown in.

c. For the Home Service battalions a course of musketry similar to what our Regulars fire now, halving Part II., but without any ficld practices, or marksmen's practices.

For Foreign Service battalions the same course as the Rejgulars firc, halving Part II., witlout marksmen's practices; but including individual field practices.

Quarterly boards, composed of the adjutant and the C.O. of the National Army battalions, to examine the men by batches in the skirmishing, etc. The test to be thorough, and any men who fail to qualify as efficient to do another year colour service, or pay a fine. The men to come up when they like, but must pass annually.

A musketry standard of efficiency must, of course, be set. Any man failing, to try again next musketry season. If he fails he should be struck off the rolls of the battalion, or heavily fined. After a man has done 5 years' service with tho colours of either class of battalion, he passes to the Reserve for another 5 years. The adjutants of battalions to be posted up as to the addresses of all men belonging to their battalion reserve. Every malo in England to be registered in the parish where he was born, and once he joined the National Army, so long as he was on the battalion books to notify change of address, or pay a fiue, until his final Reserve service was finished, 
Fin Home Service battalion Reservists a minimum attendance of drills to be carried out, and the man to join a rifle club and fire so many rounds at the club.

For Foreign Service battalions also a small amount of drill anuually, and a short course of musketry to be performed.

During the third 5 years a man of either battalion could, if he chose, still keep his name on the regimental books, but having once said he would be eligiblo for the second period of Reserve servica he must keep the regimental authorities posted as to his address, or bo fined.

Each year all Home Service battalions to go into camp for at least a wcek for battalion training, and a week following for brigade training, and only men who have passed the efficiency test to go to camp. Now, in each battalion area a committee should be formed of local men, who might be county J.P.'s, retired oflicers, etc., who would be responsiblo for impressing upon tho eligible youth of the district who seemed to bo likely candidates, the desirability of becoming oflicers of the National Army. A vast knowledge of tactics, fortification, law, etc., is not necessary for an officer of the junior ranks of the Natioual Army. What is wanted is a knowlodge of how to command a company or half-company in the field. For this purpose they should be practised in commanding the special squad mentioned already.

When they havo learnt that part of their duties, then they can go to advanced classes, which should be formed in every command. Why an officer of the National Army should be sent miles away down to London or Aldershot to go through a schiool for Auxiliary officers, and cram how to drill like the Guards, I do not know. It would be much better to attach them by the dozen if necossary, to Regilar battalions doing their annual course of military training. No Regular company that $\bar{I}$ liave ever seen in England was ever up to strength in either officers or men, and the more National Army officers, noncommissioned officers and men; that could be conveniently attached to bring Regular companics up to strength the better.

With regard to the higher ranks of the National Army there is a grand opening for all the majors of Regular units who, although thoroughly efficient officers, by no fault of thcir own are cast forth from the Army for age. These are the men who should commañd the National Army battalions.

Have an honorary colonel if you like, to draw the V.D.'s, and preside at social functions, but the real commanding officer must bo an ex-Regular, 'and one physically fit to command in the field. How many of the present Voluntecr colonels could stand a weok's campaigning even in England?. Why need thore be friction? Many corps under the present arrangement already have an honorary colonel. The ex-Regular major would be only too glad to do the training work for a small annual sum. In Germany, in every town where there are soldiers, there is an "Exercier-platz." Also the men drill on every open space in the town. Why not the same in England? Every public park and open space should be available for training Regular and National $\Lambda$ rmy tronps, and slinulh be made so by law. "If this does not produce sufficient ground, then 
havo local committees formed to take steps to procure ground by cither hire or purchase. According to Professor J. Long the distribution of the area of the British Isles is:-

$\begin{array}{lllc} & & & \text { Acres. } \\ \text { Total area of land and water } \ldots & \ldots & 56,786,741 \\ \text { Total area under crops } \ldots & \ldots & \ldots & 32,323,176 \\ \text { Mountain and heath land } & \ldots & \ldots & 12,801,617\end{array}$

Surely a great deal more of the $12,801,617$ acres can be used for training purposes than is done at present.

Wherever there is a headquarters of a National Army battalion there must also be hired or purchased sufficient fields to train the men in attack, skirmishing, etc. The money to be raised by either local subscription, or, if that does not suffice or be possible, then an Act must be passed to pay for the land out of the local rates. The land must be had. It can bo had if trouble is only taken. Every village has its cricket field. Why not its drill field? Supposing war breaks out to-morrow, and the National Army is mobilised. Where are the troops to do their training that Mr. Haldane says they will have time to do? They cannot all go to Aldershot and Salisbury. As it is theso places are already overcrowded, and troops during tho training season fairly jostle and tumble over each other at both. Why not think about training grounds and areas now, in peace time, whilst time is available?

Moreover, if the local tax-payers have to provide training ground for their local troops they will insist on value for their money, and take an interest in the. training of their local corps. Rifie ranges are a difficulty certainly, but $I$ think that a great many more ranges could be obtained and used if the Swiss system of safety ranges was used. Since the National Army home service battalions are not going to do field practices, why should not ranges be constructed firing into tall stop butts, or into small hills, the men firing from the butts being prevented from firing wildly, or over the top of the butts, by means of the safety screens? Then there would not bo the necessity for men laving to travel by train for miles to a range considered safe according to present ideas, and waste half 3 day getting backwards and forwards. A range. such as I have described, would not need to have a danger-area behind it, and need not exceed 600 yards in length for a lome service battalion. Foreign service battalions to fire on longer ranges, as at present existing. If, however, it is foind impossible to have a range near the battalion headquarters; then men in uniform by Act of Parliament to travel free, a rebate on the rateable value of the railways giving free passage to be given by the tax collectors. Thus the cost of railway journeys would be felt by nobody.

Now the National Army cavaliy must, we have scen, be trained to a much higher standard than the present Yeomanry. If this affects numbers, let it be so, and substitute corps of cyclist scouts instead.

National Army field artillery units to be armed with the old 15-pounder B.I. gun now being discarded by the Regular artillery.

$\Lambda s$ it is quite impossible to train gun layers and range takers except with the expenditure of mucl time and trouble, it will; I 
think, be necessary to have all National Army batteries composed of semi-permanent troops, that is to say, let them be civilians at ordinary times, but pay them whatever rate will produce the requisite numbers for the necessary amount of training. Bearer companics and transport arrangements are more a case for careful organisation and registration of horses, vehicles, harmess, etc., than actually training men. And all these troops should be organised into brigades of all arms; that is, a brigade might be composed of :-
4 battalions.
1 squadron.
1 brigade field artillory.
1 bearer company.
1 supply and transport column.

Complete brigades being formed of Foreign Service or Home Service units. (See Appendix B.) The British Isles to be divided up into areas of defence. To eacli area allot one or more field brigades according to the vulnerability of the coast from a point of view of raids. To each group of, say, 3 brigades, appoint a divisional commander and staff. Each brigade having, of course, its commander with brignde-major.

Each brigade to have every detailed arrangement made for mobilisation at a moment's notice.

Each battalion, battery, cavalry regiment, etc., to have mobilisation equipment for numbers similar to the same units of the Regular Army when at war strength. Every corps to be at once clotlied-in service dress, and service dress for mobilisation numbers to be stored at battalion headquarters.

No brigades to be sent for training out of their defence areas.

A training ground for each area to be provided large enough to encamp and train a brigade at least.

Schemes to be framed annually for training brigades to march rapidly; and concentrate for operations against raids or big landings.

Once in 5 years large manceuvres to be carried out in each command. For this purpose the MLanouvre Act must bo made easier of application, and its powers extended so that troops can move anywhere, subject, of course, to liberal compensation being granted. Tho manouvres generally to take the form, say, of half-a-rlozen cruisers landing Regular troops unexpectedly, when they could and whero they could, during the prescribed time, the National $\Lambda$ rmy of the command to mobilise and march to repel raiders or invaders. The National Arny troops taking part to be merely warned that they would be mobilised between certain dates, so that the C.O.'s could obtain-the names of the men willing to turn out.

Have everything real, and, therefore, interesting to the men, and avoid make-belief schemes. In short, treat the-National Army seriously. One can hardly do anything but smile at present ideas when we find the Arsenal at Woolwich providing a Toluntecr corps, when, in case of war, every man in the Arsenal would be working day and night. How can they be expected to repel invaders and turn out guns, etc., at one and the same time?

Of course, before all this working arrangement has been perfected money will have had to be expended for training grounds, ranges, equipment, etc., but one camnot make bricks witlout straw, though. 
wo try very hard to do so in the Regular Army. There a certain cexpenses that must be paid if you want to have an effic. Army. 'There is also a limit to the depth to which the most patriot: iglish:man will put his hands into his pocket if he sees that he wumself is to pay whilst others do not.

Encourage soldiering in every way, by well-cut showy uniforms, iby advertising, by well-written articles in all the papers that the poople read, and, if necessary, subsidise these papers if they encourage tho Army: by taking its part against Socialists, and Radicals in I'arliamont; by honouring and upholding the officers in the performance of their duties, instead of allowing them to be belittled by ignorant people; but do not expect tho Army, National or Regular, to pay for themselves whilst other lazy and umpatriotic people look on and jeer.

Aud lastly, encourage patriotism and a love of one's country by early teaching in every school throughout the land, that it is every man's duty to defend his country.

By being an armed nation alone we shall not; of course, become more prosperous or ready to withstand the world in arms, but if every man in the British Isles is not only a partly trained soldier, but also a true patriot in every sense of the word, then we may look forward with easy minds and consciences, and be able to hold our own in any future great struggle for national existence.

\section{APPENDIX A.}

Showiug-how National Army Recruiting Agents could be distributed in Yorkshire.

In Yorkshire thero are:-

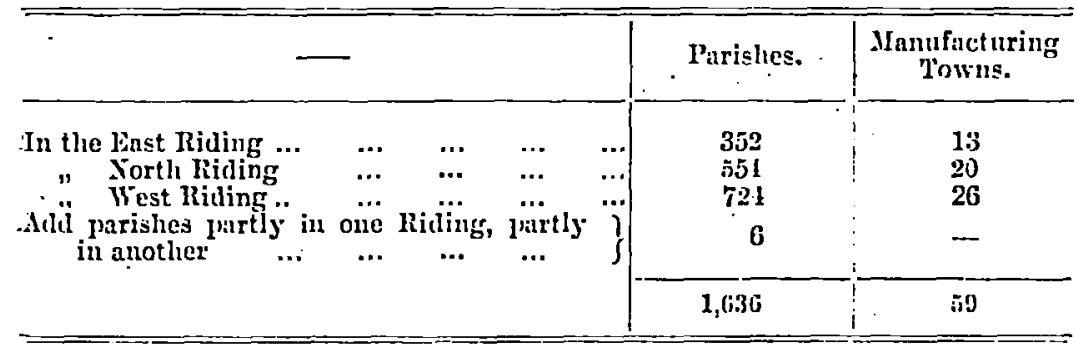

Now, there are at present in Yorkshiro 33 units of Auxiliary 'forces, as at present constituted. Each unit has a headquarters. 'Therefore, 49 parishes would have to be allotted to each headquarters under the new scheme, for recruiting purposes.

The male population of Yorkshire is $1,750,896$. If 1 in every 5 was fit to bear arms there would be 350,179 available men in the county. Therefore, each of the 33 headquarters would have an average of 10,611 fit men to draw upon.

But each lieadquarters has an average of 49 parishes to be allotted. And each parish is to have a Recruiting Agent to distribute literature and posters, and to interview recruits.

Therefore, each agent would only have to visit 10,611 , dividerl by 49 , men. This only gives 216 men to cach agent. This number is not excessive, as the agents need only work their district annually. 


\section{APPENDIX B.}

Showing grouping of National Army units into Brigados and Divisions for the County of Yorkshire:-

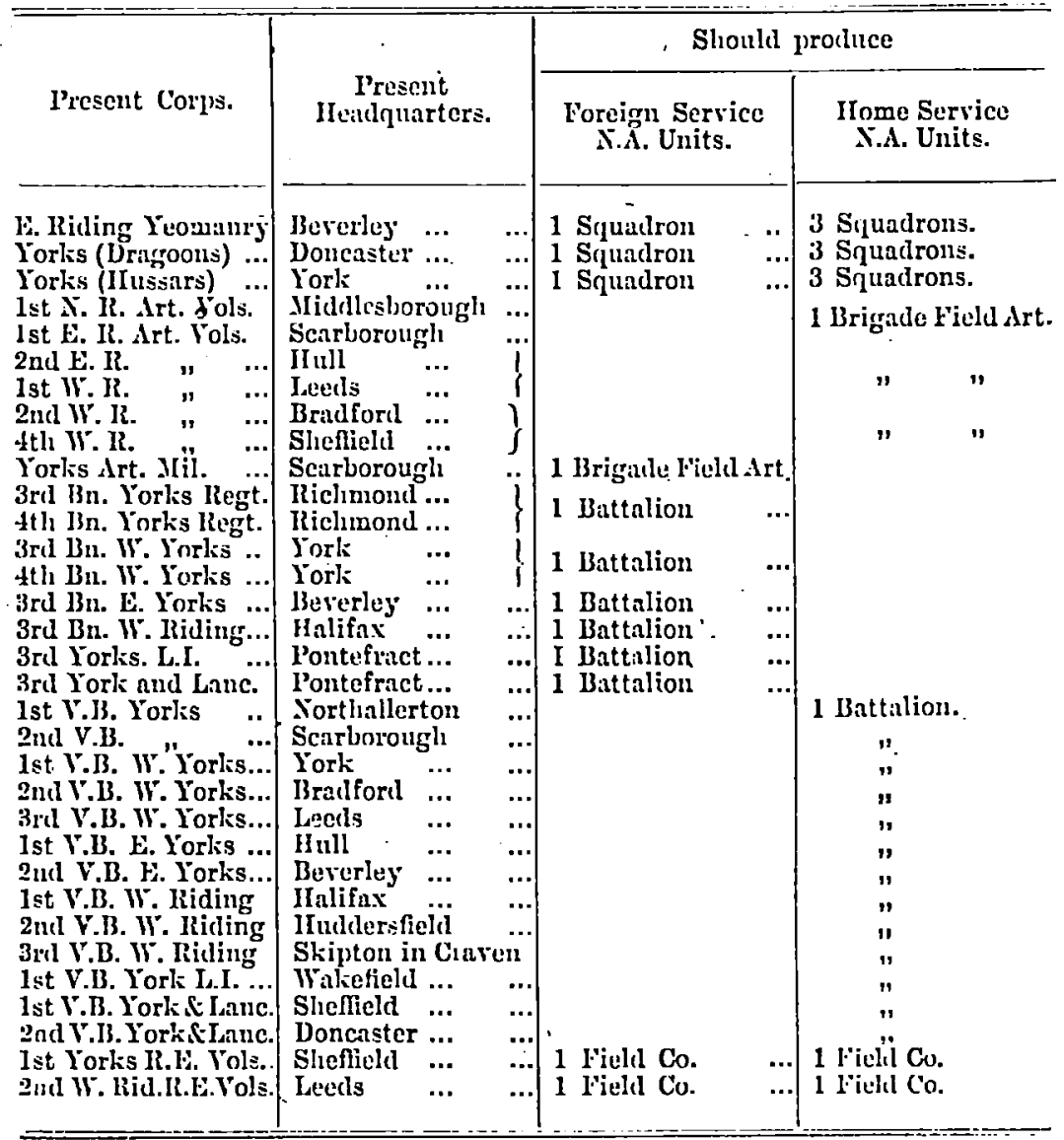

So that in Yorkshire alone we might obtain:-

For the National Army Foreign Service units.

3 Squadrons.

1 Brigade Field Artillery.

2 Field Company Engineers.

6 Battalions.
For the National Army Homo Service units.

12 Squadrons.

3 Brigades Field Artillery.

2 Field Company Engineers.

13 Battalions.

So that Yorkshire could furnish a complete brigade of all arms for foreign service. Also a complete division of all arms for home defence service ( 3 brigades to a division).

Surplus units would be united to unils of neighbouring countics, thus forming complete brigades and divisions all over Fingland. 
198 IS A NATIONAL ARMY NECESSIIY FOH THE BHITISU ISLES?

Tho Yorkshiro Home Service National Army units might be divided as follows:- Divisional Headquarters.

York.

1st Brig. IIeadqtrs. 2nd Brig. Incadqtrs. 3rd Brig. IIeadqutrs.

Beverley. Halifax: Richmond.

The 1st and 2nd Brigades to have the defence of the coast between Scarborougl and Spurn Head (inclusive), allotted to them. The 3rd Brigade to have the defence of the coast between Scarborough and Tees Bay allotted to it.

Two brigades to be allotted to the southern portion of Yorkshire, as the coast there is easier for landing purposes than futher north. Surplus brigades from Lancashire could back up the Yorkshire brigades, as no large raids are likely to take place in the Irish Sea.. 